\title{
Effects of diet on development and reproductive fitness of two predatory coccinellids (Coleoptera: Coccinellidae)
}

\author{
Mohammad A. MIRHOSSEINI, M. ReZA HOSSEINI and M. AmiN JALALI* \\ Department of Plant Protection, Faculty of Agriculture, Vali-e-Asr University of Rafsanjan, Rafsanjan, Iran; \\ e-mails: ma.jalali@vru.ac.ir; moa.mirhosseini@yahoo.com; karmania84@gmail.com
}

Key words. Coleoptera, Coccinellidae, Oenopia conglobata, Cheilomenes sexmaculata, Aphididae, Aphis gossypii, Psyllidae, Agonoscena pistaciae, Ephestia kuehniella eggs, food suitability, life table

\begin{abstract}
Studies of prey suitability are needed to develop efficient mass rearing programs for generalist predators and to understand their potential contribution to integrated pest management. A laboratory study was conducted to evaluate the development and reproductive success of two predatory coccinellids, Oenopia conglobata (L.) and Cheilomenes sexmaculata (Fabricius), reared on diets of the common pistachio psyllid, Agonoscena pistaciae Burckhardt \& Lauterer, the cotton aphid, Aphis gossypii (Glover) or a reference diet of Ephestia kuehniella Zeller eggs. Development and reproductive performance of the two coccinellids varied with diet, but egg fertility and immature survival did not. The developmental period (egg-adult) was shortest for both species on A. gossypii. This prey also yielded the shortest preoviposition period and greatest fecundity for $C$. sexmaculata. The psyllid diet was superior for reproduction in O. conglobata. For both predators, eggs of E. kuehniella were a better diet for development than for reproduction. Life table data indicated that the arboreal $O$. conglobata was better adapted to A. pistaciae on pistachio trees and might be a more effective biocontrol agent for this pest, despite the fact that $C$. sexmaculata had a higher intrinsic rate of increase on all diets.
\end{abstract}

\section{INTRODUCTION}

Most coccinellid species (about 90\%) are predaceous, representing an important component of the natural enemies of Sternorrhyncha (aphids, coccids, aleyrodids and psyllids), among the most dangerous group of crop pests (Hodek et al., 2012). Coccinellids range widely from stenotopic to eurytopic species. Some species such as Oenopia (Synharmonia) conglobata (L.) are known to be restricted to deciduous trees (Hodek \& Honěk, 1996). Oenopia conglobata is one of the most important predators of Agonoscena pistaciae Burckhardt \& Lauterer (Hemiptera: Psyllidae), a key pistachio pest in Iran (Mehrnejad \& Jalali, 2004). Field observations in Southeastern Iran show that this species is a common coccinellid in pistachio trees from April to October (Mehrnejad et al., 2011; Salehi et al., 2013) and mainly prefer to remain on psyllid-infested pistachio leaves even when aphids, especially the cotton aphid, Aphis gossypii (Glover), are abundant on herbaceous plants such as Alhagi sp. and Glycyrrhiza sp. in and around pistachio plantation areas. Earlier in March, however, when $O$. conglobata adults emerge from hibernation, the overwintered adults of $A$. pistaciae begin to deposit eggs on pistachio leaves and so the ladybirds may have to spend one generation on aphid-infested herbaceous plants (Jalali, 2001). Cheilomenes sexmaculata (Fabricius) is another psyllid predator in pistachio orchards; however, it does not appear in pistachio orchards until early July (Mehrnejad et al., 2011) when the weather is warmer. Both of these ladybeetles have been frequently reported as potential bio- logical control agents of aphids and psyllids from different agro-ecosystems around the world, especially Asia and Europe (e.g. Fye, 1981; Khan \& Khan, 2002; Erler, 2004; Singh \& Omkar, 2009; Kenis et al., 2010; Rondoni et al., 2012).

Prey quality has a direct impact on the growth, development and reproduction of predatory insects (Thompson, 1999). The suitability of a prey species can be evaluated by measuring its effect on biological attributes of the predator (Kalushkov \& Hodek, 2001). Reproduction requires high energy resources that are supplied by food, which is a major regulatory factor in reproductive success (Houck, 1991). In order to understand the behaviour, biology and ecology of insects and develop pest management strategies, it is important to have a good knowledge of how insects interact with their food sources. Most coccinellid predators survive on a "mixed diet" composed of "essential" and "alternative" prey (Hauge et al., 1998; Evans et al., 1999; Nielsen et al., 2002). Essential prey supports development and reproduction, whereas alternative prey enables adults to survive when essential prey is scarce (Hodek, 1962; Mills, 1981; Evans et al., 1999). Kalushkov \& Hodek (2001) suggest that quantitative data on a predator's rate of development, survival and reproduction indicate the adequacy of the prey. Although there have been several earlier studies evaluating the effects of diet quality and quantity on development and reproduction of $O$. conglobata and C. sexmaculata (e.g. Patnaik \& Sahu, 1980; Agarwala \& Choudhuri, 1995; Sugiura \& Takada, 1998), only a few studies have constructed life tables for $O$. conglobata (Mehrnejad \&

\footnotetext{
* Corresponding author.
} 
Jalali, 2004; Hassani et al., 2009) and there are no detailed reports of food effects on life table parameters of $C$. sexmaculata. For a successful biological control program using a specific natural enemy, it is necessary to determine its population characteristics; life table studies are a powerful tool for such evaluations (Carey, 1993; Wittmeyer \& Coudron, 2001). The objective of this study was to compare the development, reproduction and life table parameters of $O$. conglobata and C. sexmaculata on two natural prey species, A. pistaciae, a key pest of pistachio trees in Iran, and A. gossypii, a dominant aphid species on herbaceous plants in pistachio orchards (Jalali, 2001). The results may help for better understanding of the potential of these predators for augmentative biological control of key pests in pistacchio. Life table analysis can indicate which are the more promising candidates, both for mass rearing and for their performance in the field. Moreover, since the use of factitious food may make mass-rearing more economic (De Clercq, 2004), we also evaluated the quality of E. kuehniella eggs for development and reproduction of these two coccinellids.

\section{MATERIAL AND METHODS}

\section{Stock cultures}

Adults of $O$. conglobata and $C$. sexmaculata were originally collected from pistachio trees (Pistacia vera), infested by the common pistachio psyllid, Agonoscena pistaciae Burckhardt \& Lauterer, in a pistachio garden at Vali-e-Asr University of Rafsanjan, Rafsanjan, Iran (Geocoding: 30²3'39.24"N and 55 55'39.25"E). Fresh pistachio leaves infested by $A$. pistaciae were obtained daily from a pistachio garden and were transferred to the laboratory for the experiments on psyllids. The colony of melon aphid (Aphis gossypii) was reared on cucumber (Cucumis sativus) at $25 \pm 2^{\circ} \mathrm{C}$ and $60 \pm 10 \% \mathrm{RH}$, and a photoperiod of $16 \mathrm{~L}: 8 \mathrm{D}$ in greenhouse. A colony of the Mediterranean flour moth (Ephestia kuehniella) was maintained in an insectary on wheat flour at 27 $\pm 1{ }^{\circ} \mathrm{C}$ and $50 \pm 10 \% \mathrm{RH}$, and a photoperiod of $16 \mathrm{~L}: 8 \mathrm{D}$. Fresh eggs deposited by female moths were kept for at least one day in a refrigerator $\left(-18^{\circ} \mathrm{C}\right)$ before being used in the experiments. The stock population of $O$. conglobata and $C$. sexmaculata were reared separately on each of three diets (nymphs of $A$. pistaciae, A. gossypii and eggs of E. kuehniella) under controlled conditions of $27.5 \pm 1{ }^{\circ} \mathrm{C}, 50 \pm 10 \% \mathrm{RH}$ and $16 \mathrm{~L}: 8 \mathrm{D}$ photoperiod to obtain a new generation of each predator for the experiments. Based on earlier studies, these environmental conditions are almost optimum for laboratory rearing (shorter development time, lower mortality and higher reproduction output) of both coccinellids (Mirhosseini, 2013; Jalali et al., 2014).

\section{Development and mortality}

Only eggs laid within the previous $12 \mathrm{~h}$ were used for the start of each experiment. The egg clusters (approximately 150 eggs) from the first laboratory generations of $O$. conglobata and $C$. sexmaculata were reared on each of the three diets, placed separately in Petri dishes $(6 \times 1.5 \mathrm{~cm})$ under growth chamber conditions (27.5 $\pm 1{ }^{\circ} \mathrm{C}, 50 \pm 10 \% \mathrm{RH}, 16 \mathrm{~L}: 8 \mathrm{D}$ photoperiod). To exclude cannibalism, the number of eggs was carefully noted for each Petri dish. Every 12 h, we counted the number of hatched eggs and checked for unhatched or lost eggs. We never noted missing eggs or dead larvae. Moreover, eggs which did not hatch were observed under a stereomicroscope to rule out any egg cannibalism. After egg hatch, 50 first instar larvae $(<12$ h old) were carefully transferred into Petri dishes $(6 \times 1.5 \mathrm{~cm})$ individually. Each larva was supplied with one of the three diets each day until pupation. The diets (eggs of E. kuehniella or different instars of psyllid or aphid nymphs) were provided ad libitum per Petri dish. The egg, larval and pupal development times and the mortality of pre-adult stages were recorded every $12 \mathrm{~h}$. After adult emergence, they were weighed and sexed. These adults were used to assess life table parameters.

\section{Life table study}

15 freshly matured pairs of $O$. conglobata and C. sexmaculata adults were randomly selected from each diet treatment for life table studies. Females were placed separately in $100 \mathrm{~mm}$ diameter Petri dishes under the experimental conditions described above. To ensure egg fertilization, each female was paired with a male from its stock culture for $2 \mathrm{~h}$ every other day. Different nymphal instars of the melon aphid and common pistachio psyllid were maintained ad libitum on leaf discs. Eggs of E. kuehniella on paper discs were provided ad libitum to each test female every $12 \mathrm{~h}$. Survival and fecundity of females and fertility of eggs laid were recorded twice daily for the first 21 days of adult life.

\section{Data analysis}

Before analysis, data were checked for normality using the Kolmogorov-Smirnov test (K-S test) and all were found to be normally distributed. Data were then analyzed by 2-way ANOVA (SPSS, 2006) with diet and predator species as fixed factors and, in the case of adult mass, by 3-way ANOVA with gender as an additional factor. When interaction terms were significant, independent variables were analyzed separately by one-way ANOVA. The means were compared with the Bonferoni test at $5 \%$ probability. Life table parameters were calculated using total development time, total mortality, sex ratio and reproductive data. A VBA-macro for the Jackknife method was used to calculate life table parameters for the first 21 days of adult life as described by Vantornhout et al. (2005). The parameters calculated were net reproductive rate $\left(R_{0}\right)$, intrinsic rate of population increase $\left(r_{m}\right)$, finite rate of increase $(\lambda)$ and doubling time $(D T)$. Mean Jackknife pseudo-values for each treatment were subjected to ANOVA followed by the Bonferoni test to compare life table parameters among prey-predator combinations $(a=0.05)$. Percent survival, percent fertility and sex ratio were analyzed by Chi-square test.

\section{RESULTS}

\section{Development and survival of immatures}

Mean developmental times and adult fresh weights of $C$. sexmaculata fed with the three different diets are listed in Table 1. The developmental duration of egg $(F=25.76$; $d f=2,459 ; p<0.001), \mathrm{L}_{1}-\mathrm{L}_{4}(F=67.06 ; d f=2,127 ; p<$ $0.001)$, and pupal stages $(F=4.11 ; d f=2,124 ; p=0.02)$ varied significantly between the diets. The complete developmental period was shortest $(9.14 \pm 0.07$ days $)$ when fed A. gossypii and longest (10.01 \pm 0.08 days) on A. pistaciae $(F=36.37 ; d f=2,124 ; p<0.001)$. Both males $(F=31.25$; $d f=2,58 ; p<0.001)$ and females $(F=9.09 ; d f=2,63$; $p<0.001)$ showed significant variation in weight when fed different diets; however, total survival (egg-adult) did not vary significantly between diets $\left(x^{2}=1.29 ; d f=2 ; p=\right.$ $0.525)$.

Although the time to egg hatch for $O$. conglobata did not vary significantly with $\operatorname{diet}(F=2.42 ; d f=2,237 ; p=$ $0.09)$, the 1 -way ANOVA for larval development times $(F$ $=125.58 ; d f=2,167 ; p<0.001)$, to pupae $(F=58.16 ; d f=$ 
TABLE 1. Development time (days) for egg, larval $\left(\mathrm{L}_{1}-\mathrm{L}_{4}\right)$, pupal and total immature stage, total survival (egg-adult) and adult weight of Cheilomenes sexmaculata and Oenopia conglobata at $27.5^{\circ} \mathrm{C}$, fed on a factitious food, Ephestia kuehniella eggs and two natural prey, Agonoscena pistaciae and Aphis gossypii.

\begin{tabular}{|c|c|c|c|c|c|c|c|c|}
\hline \multirow{2}{*}{$\begin{array}{l}\text { Coccinellid } \\
\text { species }\end{array}$} & \multirow{2}{*}{ Food } & \multicolumn{4}{|c|}{ Developmental time $^{a}$} & \multirow{2}{*}{$\begin{array}{c}\text { Total } \\
\text { survival }(\%)\end{array}$} & \multicolumn{2}{|c|}{ Adult weight ${ }^{\mathrm{a}}(\mathrm{mg})$} \\
\hline & & Egg & $\mathrm{L}_{1}-\mathrm{L}_{4}$ & Pupa & Total & & Female & Male \\
\hline \multirow{3}{*}{ C. sexmaculata } & A. pistaciae & $1.88 \pm 0.02 \mathrm{c}$ & $5.38 \pm 0.05 \mathrm{~d}$ & $2.78 \pm 0.04 \mathrm{e}$ & $10.01 \pm 0.08 \mathrm{~d}$ & 73.49 & $8.65 \pm 0.37 b c$ & $6.45 \pm 0.25 \mathrm{de}$ \\
\hline & A. gossypii & $1.85 \pm 0.02 \mathrm{c}$ & $4.38 \pm 0.06 f$ & $2.92 \pm 0.03 d$ & $9.14 \pm 0.07 f$ & 75.12 & $10.75 \pm 0.33 a$ & $9.09 \pm 0.24 a$ \\
\hline & E. kuehniella eggs & $1.99 \pm 0.01 b$ & $4.97 \pm 0.07 \mathrm{e}$ & $2.79 \pm 0.04 \mathrm{de}$ & $9.76 \pm 0.08 \mathrm{e}$ & 67.63 & $9.84 \pm 0.35 \mathrm{ab}$ & $7.96 \pm 0.21 b$ \\
\hline \multirow{4}{*}{ O. conglobata } & A. pistaciae & $2.44 \pm 0.02 \mathrm{a}$ & $8.09 \pm 0.02 b$ & $4.92 \pm 0.04 a$ & $15.44 \pm 0.04 b$ & 81.46 & $8.83 \pm 0.19 b$ & $7.23 \pm 0.13 c$ \\
\hline & A. gossypii & $2.49 \pm 0.03 \mathrm{a}$ & $7.61 \pm 0.09 c$ & $4.26 \pm 0.05 c$ & $14.34 \pm 0.09 c$ & 82.86 & $8.21 \pm 0.18 c$ & $7.01 \pm 0.10 \mathrm{~cd}$ \\
\hline & E. kuehniella eggs & $2.50 \pm 0.02 \mathrm{a}$ & $9.14 \pm 0.08 \mathrm{a}$ & $4.69 \pm 0.04 b$ & $16.30 \pm 0.10 \mathrm{a}$ & 77.12 & $7.56 \pm 0.12 \mathrm{~d}$ & $6.28 \pm 0.11 \mathrm{e}$ \\
\hline & & $\begin{array}{c}F=296.88 \\
d f=5,699 \\
p<0.001\end{array}$ & $\begin{array}{c}F=831.91 \\
d f=5,299 \\
p<0.001\end{array}$ & $\begin{array}{c}F=566.30 \\
d f=5,284 \\
p<0.001\end{array}$ & $\begin{array}{c}F=1639.07 \\
d f=5,284 \\
p<0.001\end{array}$ & $\begin{array}{c}X^{2}=8.20 \\
d f=5 \\
p=0.146\end{array}$ & $\begin{array}{c}F=19.66 \\
d f=5,149 \\
p<0.001\end{array}$ & $\begin{array}{c}F=34.80 \\
d f=5,137 \\
p<0.001\end{array}$ \\
\hline
\end{tabular}

${ }^{a}$ Means \pm SEM within the same column followed by the same letter are statistically equivalent (Bonferoni test, $\alpha=0.05$ ).

$2,155 ; p<0.001)$ and total development time $(F=151.15$ $d f=2,155 ; p<0.001)$ were significant and indicated a predator-diet interaction (Tables 1 and 2). The complete developmental period of $O$. conglobata was the shortest (14.34 \pm 0.09 days) when fed $A$. gossypii, followed by $A$. pistaciae (15.44 \pm 0.04 days) and was longest (16.30 \pm 0.10 days) when fed E. kuehniella eggs. Adult weight was affected by diet (males: $F=18.28 ; d f=2,74 ; p<0.001$ and

TABLE 2. ANOVA of developmental times and body mass at emergence of Cheilomenes sexmaculata and Oenopia conglobata, fed on a factitious food, Ephestia kuehniella eggs and two natural prey, Agonoscena pistaciae and Aphis gossypii.

\begin{tabular}{|c|c|c|c|}
\hline Source of variation & $d f$ & $F$ & $p$ \\
\hline Egg & 5 & 296.88 & $<0.001$ \\
\hline Predator & 1 & 1429.11 & $<0.001$ \\
\hline diet & 2 & 13.91 & $<0.001$ \\
\hline Predator $\times$ diet & 2 & 6.83 & 0.001 \\
\hline Error term & 699 & & \\
\hline $\mathrm{L}_{1}-\mathrm{L}_{4}$ & 5 & 831.91 & $<0.001$ \\
\hline Predator & 1 & 3751.81 & $<0.001$ \\
\hline diet & 2 & 131.17 & $<0.001$ \\
\hline Predator $\times$ diet & 2 & 60.11 & $<0.001$ \\
\hline Error term & 294 & & \\
\hline Pupa & 5 & 566.30 & $<0.001$ \\
\hline Predator & 1 & 2715.00 & $<0.001$ \\
\hline diet & 2 & 19.03 & $<0.001$ \\
\hline Predator $\times$ diet & 2 & 46.88 & $<0.001$ \\
\hline Error term & 279 & & \\
\hline Total & 5 & 1639.07 & $<0.001$ \\
\hline Predator & 1 & 7800.75 & $<0.001$ \\
\hline diet & 2 & 146.75 & $<0.001$ \\
\hline Predator $\times$ diet & 2 & 41.54 & $<0.001$ \\
\hline Error term & 279 & & \\
\hline Fresh mass of females & 5 & 19.66 & $<0.001$ \\
\hline Predator & 1 & 54.33 & $<0.001$ \\
\hline diet & 2 & 5.81 & 0.004 \\
\hline Predator $\times$ diet & 2 & 17.15 & $<0.001$ \\
\hline Error term & 144 & & \\
\hline Fresh mass of males & 5 & 34.80 & $<0.001$ \\
\hline Predator & 1 & 48.94 & $<0.001$ \\
\hline diet & 2 & 27.12 & $<0.001$ \\
\hline Predator $\times$ diet & 2 & 39.10 & $<0.001$ \\
\hline Error term & 132 & & \\
\hline
\end{tabular}

females: $F=14.15 ; d f=2,81 ; p<0.001)$; however, total survival of $O$. conglobata did not differ significantly between the three diets $\left(x^{2}=1.18, d f=2, p=0.554\right)$.

Two-way ANOVA indicated significant variations in developmental (egg, larva, pupa and egg-adult) times with significant predator $\times$ diet interactions (Table 2).

\section{Reproductive potential and life table parameters on different diets}

The female reproductive potential of $C$. sexmaculata on three diets is presented in Table 3. The 1-way ANOVA was marginally non-significant for variation in length of the preoviposition period on different diets $(F=2.80 ; d f$ $=2,35 ; p=0.07)$. A non-significant difference was also recorded in the percent egg fertility on the three diets $\left(x^{2}=\right.$ $0.84 ; d f=2,35 ; p=0.655)$. Mean daily and total fecundity of $C$. sexmaculata during the first 21 days of adult life were significantly different between diets (MDF: $F=71.94 ; d f$ $=2,35 ; p<0.001$ and MTF: $F=70.85 ; d f=2,35 ; p<$ $0.001)$ with much lower egg production for ladybirds fed eggs of E. kuehniella compared to A. gossypii or A. pistaciae (Table 3).

The preoviposition period of $O$. conglobata females was statistically different across the three diets $(F=7.22 ; d f$ $=2,42 ; p<0.001$ ) (Table 3 ). Females of $O$. conglobata began laying eggs sooner when fed $A$. pistaciae (4.20 \pm 0.11 days) compared to $A$. gossypii (5.53 \pm 0.41 days) and E. kuehniella eggs $(5.87 \pm 0.38$ days $)$. Although two-way ANOVA revealed a non-significant predator $\times$ diet interaction for preoviposition period, the overall model indicated a significant interaction for fecundity (Table 4).

As with $C$. sexmaculata, egg fertility of $O$. conglobata was not affected by diet $\left(x^{2}=1.37, d f=2,42 ; p=0.505\right)$; however, the suitability of E. kuehniella eggs for egg production was the lowest among the three diets (MDF: $\mathrm{F}=$ 5.18; $d f=2,42 ; p<0.001$; MTF: $F=37.85 ; d f=2,42 ; p$ $<0.001$, Table 3).

Based upon life table analysis, E. kuehniella eggs provided the lowest nutritional quality for $C$. sexmaculata (Table 5). The intrinsic rate of increase $\left(r_{m}\right)$, and finite rate of increase $(\lambda)$ were highest when fed $A$. gossypii; however, a similar net reproductive rate $\left(R_{0}\right)$ value was obtained when 
TABLE 3. Reproduction of Cheilomenes sexmaculata and Oenopia conglobata at $27.5^{\circ} \mathrm{C}$, fed on a factitious food, Ephestia kuehniella eggs and two natural prey, Agonoscena pistaciae and Aphis gossypii ${ }^{\mathrm{a}}$.

\begin{tabular}{lccccc}
\hline Coccinellid species & Food & Pre-oviposition period (days) & Total no. of eggs & Eggs/female/day & Egg fertility (\%) \\
\hline \multirow{4}{*}{ C. sexmaculata } & A. pistaciae & $2.67 \pm 0.14 \mathrm{c}$ & $642.17 \pm 41.67 \mathrm{a}$ & $35.08 \pm 2.29 \mathrm{a}$ & 82.18 \\
& A. gossypii & $3.00 \pm 0.01 \mathrm{bc}$ & $669.00 \pm 21.91 \mathrm{a}$ & $37.17 \pm 1.22 \mathrm{a}$ & 83.63 \\
& E. kuehniella eggs & $4.09 \pm .84 \mathrm{bc}$ & $164.27 \pm 35.67 \mathrm{c}$ & $9.32 \pm 1.87 \mathrm{~d}$ & 78.64 \\
\hline \multirow{3}{*}{ O. conglobata } & A. pistaciae & $4.20 \pm 0.11 \mathrm{~b}$ & $379.93 \pm 7.47 \mathrm{~b}$ & $22.63 \pm 0.46 \mathrm{~b}$ & 86.90 \\
& A. gossypii & $5.53 \pm 0.41 \mathrm{a}$ & $267.20 \pm 17.14 \mathrm{~b}$ & $18.61 \pm 1.18 \mathrm{c}$ & 83.12 \\
& E. kuehniella eggs & $5.87 \pm 0.38 \mathrm{a}$ & $192.80 \pm 18.82 \mathrm{c}$ & $12.63 \pm 1.18 \mathrm{~d}$ & 81.49 \\
\hline & $F=12.29$ & $F=82.31$ & $F=66.55$ & $X^{2}=2.60$ \\
& & $d f=5,82$ & $d f=5,82$ & $d f=5,82$ & $d f=5$ \\
\hline
\end{tabular}

${ }^{a}$ Data are for the first 21 days of adult life. ${ }^{b}$ Means \pm SEM within the same column followed by the same letter are statistically equivalent (Bonferoni test, $\alpha=0.05$ ).

reared on both $A$. gossypii and $A$. pistaciae $(p=0.546)$. The population doubling time $(D T)$ was shortest on $A$. gossypii (2.25 $\pm 0.14 \times 10^{-2}$ days) and longest on E. kuehniella eggs $\left(3.32 \pm 2.04 \times 10^{-2}\right.$ days $)$.

Net reproductive rate $\left(R_{0}\right)$, intrinsic rate of increase $\left(r_{m}\right)$ and finite rate of increase $(\lambda)$ were highest and population doubling time (DT) was the lowest when fed $A$. pistaciae, followed by $A$. gossypii. Life table parameters were weakest for coccinellids reared on E. kuehniella eggs (Table 5). Further, the effect of studied factors and their interaction was significant for the parameters, $R_{0}, r_{m}, \lambda$ and DT (Table 6).

\section{DISCUSSION}

Food quality strongly influenced the development and reproduction of the two coccinellids. Differences in the life history data of $C$. sexmaculata and $O$. conglobata on the three diets were significant, indicating major differences in prey suitability. Although E. kuehniella eggs were probably an adequate diet for the development of the two ladybird species, C. sexmaculata in particular, it was clearly an inferior diet for reproduction in both species. Females of the two predators that were offered E. kuehniella eggs

TABLE 4. ANOVA of reproductive parameters of Cheilomenes sexmaculata and Oenopia conglobata, fed on a factitious food, Ephestia kuehniella eggs and two natural prey, Agonoscena pistaciae and Aphis gossypii.

\begin{tabular}{lccc}
\hline Source of variation & $d f$ & $F$ & $p$ \\
\hline Preoviposition period & 5 & 12.15 & $<0.001$ \\
$\quad$ Predator & 1 & 40.24 & $<0.001$ \\
diet & 2 & 7.40 & 0.001 \\
Predator $\times$ diet & 1 & 1.78 & 0.175 \\
$\quad$ Error term & 77 & & \\
\hline Daily fecundity & 5 & 66.04 & $<0.001$ \\
$\quad$ Predator & 1 & 62.02 & $<0.001$ \\
diet & 2 & 101.38 & $<0.001$ \\
Predator $\times$ diet & 2 & 33.27 & $<0.001$ \\
Error term & 77 & & \\
\hline Total fecundity & 5 & 81.02 & $<0.001$ \\
$\quad$ Predator & 1 & 108.92 & $<0.001$ \\
diet & 2 & 105.27 & $<0.001$ \\
Predator $\times$ diet & 2 & 41.71 & $<0.001$ \\
Error term & 77 & & \\
\hline
\end{tabular}

expressed a much lower daily and total fecundity compared with females fed natural prey. The lower fresh body weight on the moth egg diet and the higher reproductive output on aphid and psyllid diets might be due to increased prey consumption on the natural prey, leading to better conversion of food into eggs (Dixon \& Agarwala, 2002; Honěk et al., 2008; Vargas et al., 2012) and vice versa with less suitable diet (i.e. eggs of E. kuehniella). Earlier studies have shown that in certain coccinellids (Michels \& Flanders, 1992; Pervez \& Omkar, 2004) including C. sexmaculata (Omkar \& Bind, 2004), there is a positive correlation between the amount of food consumed by the larvae and the number of eggs they subsequently produced; however, we did not record the rate of food consumption in our study. The differences in reproductive rates observed here might be related to the fact that ingested natural prey may be converted to body mass more efficiently than unnatural foods (Jalali et al., 2009). The finding that E. kuehniella eggs are a much better diet for development than for reproduction in both ladybird species supports the argument by Michaud (2005) that larvae and adults of ladybird beetles may have different nutritional requirements. This was also observed in Coleomegilla maculata De Geer (Michaud \& Jyoti, 2008; Riddick et al., 2014) and Hippodamia convergens Guerin (Michaud, 2000). Despite the wide variation in development times and oviposition output, diet had no significant effect on egg fertility. In the present study, fecundity proved a much better predictor of reproductive success; in both coccinellids, females consuming natural (aphid or psyllid) prey deposited significantly more eggs than those feeding on moth eggs, despite producing similar progenies. Aphid and psyllid diets appear to be much better protein sources for ovigenesis but are probably similar to E. kuehniella eggs in some nutrients required for egg fertility. As with the natural diets, E. kuehniella eggs are sufficiently palatable and nutritious enough to support the yolk content needed for nourishing the embryo as well as providing healthy and motile sperm in males; however, this monotypic diet should be supplemented with some plant material such as pollen to enhance reproductive output, as observed in some other predatory ladybirds such as Adalia bipunctata L. (De Clercq et al., 2005; Jalali et al., 2009) and Harmonia axyridis (Pallas) (Berkvens et al., 2008) and 
TABle 5. Life table parameters of female Cheilomenes sexmaculata and Oenopia conglobata at $27.5^{\circ} \mathrm{C}$, fed on a factitious food, Ephestia kuehniella eggs and two natural prey, Agonoscena pistaciae and Aphis gossypii ${ }^{\mathrm{a}}$.

\begin{tabular}{|c|c|c|c|c|c|}
\hline \multirow{2}{*}{$\begin{array}{l}\text { Coccinellid } \\
\text { species }\end{array}$} & \multirow[b]{2}{*}{ Diet } & \multicolumn{4}{|c|}{ Life table parameter ${ }^{\mathrm{b}}$} \\
\hline & & $\begin{array}{l}\text { Net reproductive rate, } \\
R_{0} \text { (females/female) }\end{array}$ & $\begin{array}{l}\text { Intrinsic rate of increase, } \\
r_{m}(\text { females/female/day })\end{array}$ & $\begin{array}{l}\text { Finite rate of increase, } \\
\lambda \text { (females/female/day) }\end{array}$ & $\begin{array}{l}\text { Doubling time, } \\
D T \text { (days) }\end{array}$ \\
\hline \multirow{3}{*}{ C. sexmaculata } & A. pistaciae & $254.9453 \pm 1.3834 \mathrm{a}$ & $0.2831 \pm 0.0004 b$ & $1.3272 \pm 0.0005 b$ & $2.4489 \pm 0.0035 \mathrm{e}$ \\
\hline & A. gossypii & $256.8478 \pm 0.5620 \mathrm{a}$ & $0.3082 \pm 0.0002 \mathrm{a}$ & $1.3609 \pm 0.0003 \mathrm{a}$ & $2.2494 \pm 0.0014 \mathrm{f}$ \\
\hline & E. kuehniella eggs & $55.3324 \pm 1.0982 \mathrm{e}$ & $0.2090 \pm 0.0013 c$ & $1.2324 \pm 0.0016 \mathrm{c}$ & $3.3184 \pm 0.0204 d$ \\
\hline \multirow{6}{*}{ O. conglobata } & A. pistaciae & $161.4717 \pm 0.2121 b$ & $0.1824 \pm 0.0001 d$ & $1.2001 \pm 0.0001 \mathrm{~d}$ & $3.8003 \pm 0.0011 \mathrm{c}$ \\
\hline & A. gossypii & $109.0710 \pm 0.4674 \mathrm{c}$ & $0.1796 \pm 0.0003 \mathrm{e}$ & $1.1967 \pm 0.0003 \mathrm{e}$ & $3.8595 \pm 0.0057 \mathrm{~b}$ \\
\hline & E. kuehniella eggs & $77.3174 \pm 0.5043 \mathrm{~d}$ & $0.1587 \pm 0.0003 \mathrm{f}$ & $1.1720 \pm 0.0003 \mathrm{f}$ & $4.3680 \pm 0.0079 \mathrm{a}$ \\
\hline & $F$ & 13772.98 & 16637.61 & 17411.56 & 11152.13 \\
\hline & $d f$ & 5,88 & 5,88 & 5,88 & 5,88 \\
\hline & $p$ & $<0.001$ & $<0.001$ & $<0.001$ & $<0.001$ \\
\hline
\end{tabular}

${ }^{\mathrm{a}}$ Data are for the first 21 days of adult life. ${ }^{\mathrm{b}}$ Means \pm SEM within the same column followed by the same letter are statistically equivalent (Bonferoni test, $\alpha=0.05$ ).

other predatory insects (Cocuzza et al., 1997; Vandekerkhove \& De Clercq, 2010); however, further studies are necessary to identify suitable plant material for $C$. sexmaculata and O. conglobata.

It is well known that the survival rate of many coccinellid species is closely associated with the quality of their diet (e.g. Michaud, 2000; Omkar \& Srivastava, 2003; Zhang et al., 2012; Mehrparvar et al., 2013; Silva et al., 2013). The fact that the three food treatments in our study were from different insect taxonomic groups (and thus possibly with completely different nutritive quality), food quality did not affect immature survival of either coccinellid species. It appears that on the suboptimal diet, larvae of the two ladybird species decrease their development rate and possibly consume higher amounts of food to grow to a threshold size critical for pupation and subsequent emergence to adult (see Phoofolo et al., 2007). Thus, if the quality of

TABLE 6. ANOVA of life table parameters of Cheilomenes sexmaculata and Oenopia conglobata, fed on a factitious food, Ephestia kuehniella eggs and two natural prey, Agonoscena pistaciae and Aphis gossypii.

\begin{tabular}{lrcr}
\hline Source of variation & $d f$ & $F$ & $p$ \\
\hline$r_{m}$ Predator & 5 & 16673.61 & $<0.001$ \\
$\quad$ diet & 1 & 55346.35 & $<0.001$ \\
$\quad$ Predator $\times$ diet & 2 & 8511.94 & $<0.001$ \\
$\quad$ Error term & 83 & 3336.98 & 0.001 \\
\hline$\lambda \quad$ & 5 & 17411.56 & $<0.001$ \\
$\quad$ Predator & 1 & 57136.46 & $<0.001$ \\
diet & 2 & 8964.40 & $<0.001$ \\
Predator $\times$ diet & 2 & 3819.22 & $<0.001$ \\
Error term & 83 & & \\
\hline$D T$ & 5 & 11152.13 & $<0.001$ \\
$\quad$ Predator & 1 & 40580.15 & $<0.001$ \\
$\quad$ diet & 2 & 5619.10 & $<0.001$ \\
Predator $\times$ diet & 2 & 600.38 & $<0.001$ \\
Error term & 83 & & \\
\hline$R_{0}$ Predator & 5 & 13772.98 & $<0.001$ \\
$\quad$ diet & 1 & 14786.52 & $<0.001$ \\
Predator $\times$ diet & 2 & 20309.28 & $<0.001$ \\
Error term & 2 & 6889.68 & $<0.001$ \\
\hline
\end{tabular}

food is just enough to allow growth and development to this threshold size, then all individual larvae should potentially survive to become adults despite differences in body weight (Table 1). This may be evidence of an adaptation for coping with suboptimal foods under field conditions when optimal prey is scarce.

Based on life table data, the values for intrinsic rate of natural increase of $C$. sexmaculata were higher than those of $O$. conglobata on each diet tested. Thus, $C$. sexmaculata might be a more efficient natural enemy than $O$. conglobata when it preys on psyllids or aphids. C. sexmaculata showed much greater potential for increase of its population than $O$. conglobata regardless of the food they consume; however, the three diets showed major differences in their suitability. Although $A$. gossypii was the most suitable diet for C. sexmaculata, resulting in greater values for net reproductive rate, intrinsic rate of natural increase and finite rate of increase and the shortest doubling time, the life table parameters of $O$. conglobata were the best when it developed on A. pistaciae. O. conglobata is known to thrive principally in arboreal habitats (Hodek \& Honěk, 1996). Field observations by Mehrnejad et al. (2011) showed that O. conglobata is one of the most abundant ladybirds among 17 species recorded from wild and cultivated pistachio trees in Southeastern Iran. This species is common on pistachio trees from April to October (Mehrnejad et al., 2011; Salehi et al., 2013); however, its oviposition behaviour is highly affected by psyllid abundance and the proportion of females laying eggs. The size of egg clutches decreases during midsummer. Females mainly prefer to remain on psyllid-infested pistachio leaves even when aphids, especially Aphis gossypii, are abundant on herbaceous plants such as Alhagi sp. and Glycyrrhiza sp. in and around pistachio plantation areas (Jalali, 2001; Mehrnejad et al., 2011). Although we do not know much on the food habits of $C$. sexmaculata in pistachio plantations, a 2-year field survey by Mehrnejad et al. (2011) showed that this coccinellid is much less abundant than $O$. conglobata in pistachio trees in Southeastern Iran, appearing in pistachio orchards in early July when the weather is warmer. C. sexmaculata is a common predatory coccinellid in warm and humid climate 
zones such as Far Eastern and south Asian countries (Agarwala \& Ghosh, 1988) and apparently is a stenotopic species, preferring herbaceous plants. This ladybird was introduced into North America to help control the green bug, Schizaphis graminum (Rondani), on cereals (Cartwright et al., 1977). Prey preference studies suggested that the cowpea aphid, Aphis craccivora Koch on bean plants is one of the most suitable hosts of this predaceous coccinellid (see Agarwala et al., 2001 for a review). Thus, the arboreal $O$. conglobata seems to be better adapted than $C$. sexmaculata to psyllid prey on pistachio, possibly because it evolved for a much longer period of time with this prey in pistachio habitats. The longer development time and lower fecundity of C. sexmaculata reared on psyllids is probably indicative of its poor palatability or poor quality over an aphid diet. It might also suggest the possible presence of some allelochemicals in the pistachio plant that make this prey unsuitable for $C$. sexmaculata. In other coccinellids, it is known that allelochemicals and secondary metabolites of host plants can make prey less suitable and decrease fecundity (Francis et al., 2001), and long-term coevolution between predators and prey can lead to the development of better adapted strategies for optimal use of a specific prey (Abrams, 1986; Albuquerque et al., 1997; Berthiaume et al., 2007).

In conclusion, E. kuehniella eggs were a much better diet for development than for reproduction in both predators, which suggests that suitability should be assessed independently for larval development and adult reproduction because of potentially divergent nutritional requirements between these life stages. We hypothesize that the arboreal $O$. conglobata should be better adapted to A. pistaciae on pistachio trees than $C$. sexmaculata, which evolved in close association with aphids on herbaceous plants. Although $C$. sexmaculata demonstrated a much higher intrinsic population growth potential than the other ladybird beetle, the stenotopic habit of arboreal specialists like $O$. conglobata, coupled with its tendency to remain in pistachio trees even with excess food on herbaceous plants, may make it a good biocontrol agent for some pistachio pests including A. pistaciae.

ACKNOWLEDGEMENTS. The authors thank W. Jones for a critical review of this manuscript, and M. Ziaaddini for statistical consultation. We are grateful to two anonymous reviewers whose comments improved the manuscript and to the Department of Plant Protection, Vali-e-Asr University of Rafsanjan the use of greenhouse facilities.

\section{REFERENCES}

ABrams P.A. 1986: Adaptive responses of predators to prey and prey to predators: The failure of the arms-race analogy. - Evolution 40: 1229-1247.

Agarwala B. \& Choudhuri M. 1995: Use of alternative food in rearing of aphidophagous ladybeetle, Menochilus sexmaculata. - Entomon 20: 19-23.

Agarwala B.K. \& Ghosh A. 1988: Prey records of aphidophagous coccinellidae in India. A review and bibliography. - Trop. Pest Manag. 14: 1-14.

Agarwala B.K., Bardhanroy P., Yasuda H. \& Takizawa T. 2001: Prey consumption and oviposition of the aphidophagous preda- tor Menochilus sexmaculatus (Coleoptera: Coccinellidae) in relation to prey density and adult size. - Environ. Entomol. 30: $1182-1187$.

Albuquerque G.S., Tauber M.J. \& Tauber C.A. 1997: Life-history adaptations and reproductive costs associated with specialization in predacious insects. - J. Anim. Ecol. 66: 307-317.

Berkyens N., Bonte J., Berkvens D., Deforce K., Tirry L. \& De ClercQ P. 2008: Pollen as an alternative food for Harmonia axyridis. In Roy H.E. \& Wajnberg E. (eds): From Biological Control to Invasion: The Ladybird Harmonia axyridis as a Model Species. Springer, Dordrecht, pp. 201-210.

Berthiaume R., Hébert C. \& Cloutier C. 2007: Comparative use of Mindarus abietinus (Homoptera: Aphididae) by two coccinellids (Coleoptera: Coccinellidae), the native Anatis mali and the exotic Harmonia axyridis, in a christmas tree plantation. - Environ. Entomol. 36: 319-328.

CAREY J.R. 1993: Applied Demography for Biologists with Special Emphasis on Insects. Oxford University Press, New York, $224 \mathrm{pp}$.

Cartwright B., Eikenbary R., Johnson J., Farris T. \& Morrison R. 1977: Field release and dispersal of Menochilus sexmaculatus, an imported predator of the greenbug, Schizaphis graminum. - Environ. Entomol. 6: 699-704.

Cocuzza G.E., De Clerce P., Veire M., Cock A.D., Degheele D. \& Vacante V. 1997: Reproduction of Orius laevigatus and Orius albidipennis on pollen and Ephestia kuehniella eggs. Entomol. Exp. Appl. 82: 101-104.

De Clerce P. 2004: Culture of natural enemies on factitious foods and artificial diets. In Capinera J.L. (ed.): Encyclopedia of Entomology. Kluwer, Dordrecht, pp. 650-652.

De Clerce P., Bonte M., Van Speybroeck K., Bolckmans K. \& Deforce K. 2005: Development and reproduction of Adalia bipunctata (Coleoptera: Coccinellidae) on eggs of Ephestia kuehniella (Lepidoptera: Phycitidae) and pollen. - Pest Manag. Sci. 61: 1129-1132.

Dixon A. \& Agarwala B. 2002: Triangular fecundity function and ageing in ladybird beetles. - Ecol. Entomol. 27: 433-440.

ERLER F. 2004: Natural enemies of the pear psylla Cacopsylla pyri in treated vs untreated pear orchards in Antalya, Turkey. - Phytoparasitica 32: 295-304.

Evans E.W., Stevenson A.T. \& Richards D.R. 1999: Essential versus alternative foods of insect predators: Benefits of a mixed diet. - Oecologia 121: 107-112.

Francis F., Haubruge E., Hastir P. \& Gaspar C. 2001: Effect of aphid host plant on development and reproduction of the third trophic level, the predator Adalia bipunctata (Coleoptera: Coccinellidae). - Environ. Entomol. 30: 947-952.

FyE R.E. 1981: Rearing and Release of Coccinellids for Potential Control of Pear Psylla. Agricultural Research Service (Western Region), USDA, Oakland, CA, 9 pp.

Hassani M., Mehrnejad M. \& Ostovan H. 2009: Some biological and predation characteristics of Oenopia conglobata contaminata (Col.: Coccinellidae) on the common pistachio psylla in laboratory conditions, Iran. - J. Forest Range Prot. Res. 6: $110-117$.

Hauge M.S., Nielsen F.H. \& Toft S. 1998: The influence of three cereal aphid species and mixed diet on larval survival, development and adult weight of Coccinella septempunctata. - Entomol. Exp. Appl. 89: 319-322.

Hodek I. 1962: Essential and alternative food in insects. In: Proc. of the XIth International Congress of Entomology (Vienna, 1960). Vol. 2. Organisationalskomittee des XI Internationalen Kongress für Entomologie, Vienna, pp. 697-699.

Hodek I. \& HonĚK A. 1996: Ecology of Coccinellidae. Kluwer, Dordrecht, 464 pp.

HodeK I., van EMden H.F. \& HonĚK A. (eds) 2012: Ecology and Behaviour of the Ladybird Beetles (Coccinellidae). 1st ed. Wiley-Blackwell, Chichester, 604 pp. 
HoněK A., Dixon A.F. \& Martinkova Z. 2008: Body size, reproductive allocation, and maximum reproductive rate of two species of aphidophagous coccinellidae exploiting the same resource. - Entomol. Exp. Appl. 127: 1-9.

Houck M. 1991: Time and resource partitioning in Stethorus punctum (Coleoptera: Coccinellidae). - Environ. Entomol. 20: 494-497.

Jalali M.A. 2001: Study of Food Consumption in Predatory Beetles (Col.: Coccinellidae) of the Common Pistachio Psyllid, Agonoscena pistaciae in Rafsanjan, and Compiling a Life Table in the Controlled Condition. M.Sc. Thesis, Shiraz University, Shiraz, $110 \mathrm{pp}$.

Jalali M.A., Tirry L. \& De Clerce P. 2009: Effects of food and temperature on development, fecundity and life table parameters of Adalia bipunctata (Coleoptera: Coccinellidae). $-J$. Appl. Entomol. 133: 615-625.

Jalali M., Mehrnejad M. \& Kontodimas D. 2014: Temperaturedependent development of the five psyllophagous ladybird predators of Agonoscena pistaciae (Hemiptera: Psyllidae). Ann. Entomol. Soc. Am. 107: 445-452.

Kalushiov P. \& Hodek I. 2001: New essential aphid prey for Anatis ocellata and Calvia quatuordecimguttata (Coleoptera: Coccinellidae). - Biocontr. Sci. Technol. 11: 35-39.

Kenis M., Adriaens T., Brown P., Katsanis A., Van Vlaenderen J., Eschen R., Golaz L., Zindel R., San Martin y Gomez G. \& BABENDREIER D. 2010: Impact of Harmonia axyridis on european ladybirds: Which species are most at risk. $-I O B C / W P R S$ Bull. 58: 57-59.

KHAN M.R. \& KHAN M.R. 2002: Mass rearing of Menochilus sexmaculatus Fabricius (Coleoptera: Coccinellidae) on natural and artificial diets. - Int. J. Agric. Biol. 4: 107-109.

MeHRNEJAD M.R. \& JALALI M.A. 2004: Life history parameters of the coccinellid beetle, Oenopia conglobata contaminata, an important predator of the common pistachio psylla, Agonoscena pistaciae (Hemiptera: Psylloidea). - Biocontr. Sci. Technol. 14: 701-711.

Mehrnejad M.R., Jalali M.A. \& Mirzaei R. 2011: Abundance and biological parameters of psyllophagous coccinellids in pistachio orchards. - J. Appl. Entomol. 135: 673-681.

Mehrparvar M., Mahdavi Arab N. \& Weisser W.W. 2013: Dietmediated effects of specialized tansy aphids on survival and development of their predators: Is there any benefit of dietary mixing? - Biol. Contr. 65: 142-146.

Michaud J. 2000: Development and reproduction of ladybeetles (Coleoptera: Coccinellidae) on the citrus aphids Aphis spiraecola Patch and Toxoptera citricida (Kirkaldy) (Homoptera: Aphididae). - Biol. Contr. 18: 287-297.

Michaud J. 2005: On the assessment of prey suitability in aphidophagous coccinellidae. - Eur. J. Entomol. 102: 385-390.

Michaud J. \& Jyоті J. 2008: Dietary complementation across life stages in the polyphagous lady beetle Coleomegilla maculata. - Entomol. Exp. Appl. 126: 40-45.

Michels G. \& Flanders R. 1992: Larval development, aphid consumption and oviposition for five imported coccinellids at constant temperature on Russian wheat aphids and greenbugs. - Southwest. Entomol. 17: 233-243.

Mills N. 1981: Essential and alternative foods for some British Coccinellidae (Coleoptera) [including aphid pests]. — Entomol. Gaz. 32: 197-203.

MirhosseinI M.A. 2013: Effects of Age and Mating History of Adult Males on the Female Reproductive Success and Offspring Development in Cheilomenes sexmaculata Fabricius (Col.: Coccinellidae). M.Sc. thesis, Vali-e-Asr University of Rafsanjan, $94 \mathrm{pp}$.

Nielsen F., Hauge M. \& Toft S. 2002: The influence of mixed aphid diets on larval performance of Coccinella septempunctata (Col., Coccinellidae). - J. Appl. Entomol. 126: 194-197.
OMKAR \& Bind R. 2004: Prey quality dependent growth, development and reproduction of a biocontrol agent, Cheilomenes sexmaculata (Fabricius) (Coleoptera: Coccinellidae). - Biocontr. Sci. Technol. 14: 665-673.

OMKAR \& SRIVASTAVA S. 2003: Influence of six aphid prey species on development and reproduction of a ladybird beetle, Coccinella septempunctata. - BioControl 48: 379-393.

Patnaik N. \& SAhU D. 1980: Influence of aphid host and certain artificial diets on ovipositional response and longevity of lady bird beetle, Menochilus sexmaculata (Fabr.) (Coleoptera: Coccinellidae). - Sci. Cult. 46: 103-105.

Pervez A. \& Omkar S. 2004: Prey-dependent life attributes of an aphidophagous ladybird beetle, Propylea dissecta (Coleoptera: Coccinellidae). - Biocontr. Sci. Technol. 14: 385-396.

Phoofolo M.W., Giles K.L. \& Elliott N.C. 2007: Quantitative evaluation of suitability of the greenbug, Schizaphis graminum, and the bird cherry-oat aphid, Rhopalosiphum padi, as prey for Hippodamia convergens (Coleoptera: Coccinellidae). - Biol. Contr. 41: 25-32.

Riddick E.W., Wu Z. \& RoJas M.G. 2014: Potential utilization of Artemia franciscana eggs as food for Coleomegilla maculata. - BioControl 59: 575-583.

RoNDONI G., ONOFRI A. \& RicCi C. 2012: Laboratory studies on intraguild predation and cannibalism among coccinellid larvae (Coleoptera: Coccinellidae). — Eur. J. Entomol. 109: 353-362.

Salehi T., Mehrnejad M.R. \& Pashaei Rad S. 2013: Diversity pattern of adult ladybird (Coleoptera: Coccinellidae) communities on pistachio trees in southern parts of Iran in different months. - Zool. Ecol. 23: 286-292.

Silva R.B., Cruz I., Zanuncio J.C., Figueiredo M.L.C., Zanuncio T.V. \& Serrão J.E. 2013: Spodoptera frugiperda (J.E. Smith) (Lepidoptera: Noctuidae) eggs as alternative food for rearing of lady beetles Eriopis connexa (Germar) (Coleoptera: Coccinellidae). - Biol. Contr. 64: 101-105.

SINGH K. \& OMKAR 2009: Effect of parental ageing on offspring developmental and survival attributes in an aphidophagous ladybird, Cheilomenes sexmaculata. - J. Appl. Entomol. 133: 500-504.

SPSS Inc 2006: SPSS Base 15.0 for Windows, User's Guide Computer Program, Version by SPSS Inc., Chicago, IL.

Sugiura K. \& TAKADA H. 1998: Suitability of seven aphid species as prey of Cheilomenes sexmaculata (Fabricius) (Coleoptera: Coccinellidae). - Jpn. J. Appl. Entomol. Zool. 42: 7-14.

THOMPSON S. 1999: Nutrition and culture of entomophagous insects. - Annu. Rev. Entomol. 44: 561-592.

Vandekerkhove B. \& De Clerce P. 2010: Pollen as an alternative or supplementary food for the mirid predator Macrolophus pygmaeus. - Biol. Contr. 53: 238-242.

Vantornhout I., Minnaert H.L., Tirry L. \& De Clerce P. 2005: Influence of diet on life table parameters of Iphiseius degenerans (Acari: Phytoseiidae). - Exp. Appl. Acarol. 35: 183-195.

Vargas G., Michaud J. \& Nechols J.R. 2012: Larval food supply constrains female reproductive schedules in Hippodamia convergens (Coleoptera: Coccinellidae). - Ann. Entomol. Soc. Am. 105: 832-839.

WittMeyer J. \& Coudron T. 2001: Life table parameters, reproductive rate, intrinsic rate of increase, and estimated cost of rearing Podisus maculiventris (Heteroptera: Pentatomidae) on an artificial diet. - J. Econ. Entomol. 94: 1344-1352.

Zhang S.-Z., Li J.-J., Shan H.-W., Zhang F. \& LiU T.-X. 2012: Influence of five aphid species on development and reproduction of Propylea japonica (Coleoptera: Coccinellidae). - Biol. Contr. 62: 135-139.

Received August 14, 2014; revised and accepted February 18, 2015 Prepublished online March 9, 2015 